\title{
Clinical handover of the critically ill postoperative patient: An integrative review
}

\section{Abstract}

\section{Objectives}

The clinical handover of critically ill postoperative patients from the operating theatre to the intensive care unit is a dynamic and complex process that can lead to communication and technical errors. The objectives of this integrative review were to illustrate how the use of structured handover processes between the operating theatre and intensive care unit impacts information transfer, handover duration, post-handover technical error and high risk events.

\section{Review method used}

Integrative review methodology was used to allow for the inclusion of broad research designs, summarising current knowledge from existing research and identify gaps in the literature.

\section{Data Sources}

A systematic search of electronic databases including the Cumulative Index to Nursing and Allied Health Literature (CINAHL), Cochrane library, Embase, ProQuest central and PubMed were performed. Original research articles, in either adults or paediatrics, specific to handover between an operating theatre and intensive care unit were included.

\section{Review methods}


Data extracted from studies included country of origin, sample size, number of hospital sites, study design, study aim, measures, key findings and limitations. The quality of the integrative review articles was assessed against the 'Standard Quality Assessment Criteria for Evaluating Primary Research Papers'.

\section{Results}

Ten articles meeting the inclusion criteria were included in the final analysis. Information transfer, post-handover technical errors and high risk events were positively influenced by the use of structured clinical handover tools. Handover duration did not change when using structured handover protocols.

\section{Conclusions}

The body of literature on clinical handover between operating theatre and the intensive care unit is in its early stages of development. Future research using rigorous study designs, broader populations and varied surgical procedures are needed to further evaluate the effect of clinical handover protocols.

\section{Keywords}

Critical Care; Handoff; Handover; Intensive Care; Operating Room; Operating Theatre; Perioperative 


\section{Introduction}

Patient harm from potentially avoidable medical error continues to occur frequently in health care settings world-wide. ${ }^{1-3}$ Both the Institute of Medicine and the Joint Commission on Accreditation of Health Care Organizations have reported that communication failure is the most common cause of preventable medical error. ${ }^{2}$ Communication error in clinical practice reportedly contributes up to $70 \%$ of preventable medical error resulting in death, serious physical or psychological injury to patients. ${ }^{2,3}$ Several studies have reported higher observed rates of preventable error occur in operating theatres (OT) and intensive care units (ICUs), when compared to other health care areas. ${ }^{4-6}$ Similarly, the Joint Commission reported that approximately half of communication failures were related to the clinical handover period. ${ }^{2}$ In 2007, communication during patient handover was listed as one of the World Health Organization "High Five" patient safety initiatives. ${ }^{7}$ The Joint Commission and the Australian Commission on Safety and Quality in Health Care have also identified clinical handover as an important area of focus for patient safety. ${ }^{2,3}$

\section{Background}

The clinical handover of critically ill postoperative patients from OT to the ICU involves a dynamic and complex set of processes which can influence the recovery and outcomes of vulnerable patients. ${ }^{8,9}$ Clinical handover is broadly defined as the transfer of the patient, information, equipment, professional responsibility and accountability from one professional person or group to another, and may also include strategies that promote education and teamwork. ${ }^{3,8}$ Table 1 defines other terms and definitions used in this review. Information handover involves many different people at a single point of time, each of whom has a specific perspective and focus for patient care, potentially increasing the risk of ineffective communication. ${ }^{8}$ For example, admitting a patient to the ICU from OT involves transferring 
the patient and any related equipment. If patient and equipment transfer is undertaken at the same time as information handover, then the effectiveness of communication may be compromised, shifting team focus to the disconnection, transfer and reconnection of equipment rather than on the information being relayed..$^{10}$

Ineffective communication during clinical handover can have immediate and long term consequences for the delivery of safe patient care. ${ }^{2,3,11}$ In the short term, an ineffective handover may result in information loss and technical error, delays in medical diagnosis, wrong treatment and higher incidence of life threatening adverse events., ${ }^{9,11,12}$ Potential longer term effects of ineffective handover have been reported to include increased patient complaints, hospital length of stay, and health care costs..$^{9,11,13}$

The importance of clinical handover from OT to ICU is emphasised in Segal et al's ${ }^{14} 2012$ review of handover from OT to the post anaesthesia care unit (PACU) or ICU. The majority $(n=20 / 31,65 \%)$ of studies included in this review were specific to PACU, with fewer studies being focusing on handover from OT to ICU. The applicability of research conducted in the context of post-anaesthetic recovery to ICU practice is questionable given the higher level of patient acuity and surgical complexity of patients transferred from the OT to the ICU.

Consequently, the handover process between OT and ICU is likely to be more complex because patients are sicker, require more monitoring and equipment, may be on life support, and have more interdisciplinary team members involved in care. Potentially, this higher level of complexity requires sophisticated processes of communication and consequently there is an increased likelihood of technical error during the handover process from OT to ICU. Since this review was published in 2012 there have been a further five articles published specific to handover between OT and ICU. ${ }^{11,15-18}$ To our knowledge this integrative literature review is the first in the area of handover from the OT to the ICU that has used robust systematic 
assessment criteria (Standard Quality Assessment Criteria for Evaluating Primary Research Papers).

\section{Aims}

This paper reports the findings of an integrative review which provides a synthesis and critique of existing research relating to OT to ICU clinical handover. A description of the state of the science in this important patient safety area is described. Specifically, we illustrate how the use of structured handover processes between the OT and ICU impacts information transfer, handover duration, post-handover technical error and high risk events.

\section{Methods}

Integrative review methodology was used to allow for the inclusion of both experimental and non-experimental research designs ${ }^{19}$ broadly summarising the current state of the science from existing research and to identifying gaps in the literature. ${ }^{19}$ This review process provides broad understanding of healthcare problems whilst identifying areas for future research focus, contributing to nursing science, with the potential to influence policy and nursing care. $^{19,20}$

\section{Literature search strategies}

A systematic search of electronic databases including the Cumulative Index to Nursing and Allied Health Literature (CINAHL), Cochrane library, Embase, ProQuest central and PubMed was performed. We included articles that reported original research, regardless of research design, not limited to a date range, that were specific to handover between an OT and ICU, in either the adult or paediatric context, using search terms in Table 2. Additional literature was identified through hand searching reference lists of included papers and the systematic review of Segal et al. ${ }^{14}$ Figure 1 describes the process of article identification, screening, eligibility and inclusion. 


\section{Data Extraction}

Data extraction was independently completed by one author. During data extraction, the review authors met regularly to discuss emerging queries, which were resolved through consensus. Data were extracted from primary sources and categorised according to setting and sample, study design, study aim, measures used, key findings, and study limitations. Primary sources were re-reviewed to check concepts and findings at the original source. In this review definitions were informed by the Australian Commission on Safety and Quality in Health Care or how ever defined by the study authors (Table 1).

\section{Quality Assessment}

To facilitate the inclusion of broad designs, a quality assessment tool specifically developed for this purpose was selected. ${ }^{21}$ The quality of the integrative review articles was assessed against the 'Standard Quality Assessment Criteria for Evaluating Primary Research Papers'. ${ }^{21}$ The checklist for assessing the quality of quantitative studies has previously been tested for inter-rater reliability with a level of agreement of $73 \%$ to $100 \%$. The checklist comprised 14 questions scored from 2 (yes), 1 (partial), 0 (no), or not applicable (n/a). ${ }^{21}$

\section{Results}

Search of the five databases identified a total of 100 articles. Article titles and abstracts were screened for relevance to the criteria. Reference sections of articles meeting the inclusion criteria were then hand searched and one additional article was located. After removal of duplicates, screening against the inclusion criteria and hand searching, a total of 10/101 (9.9\%) articles were included in the integrative review (Figure 1).

All studies reviewed used prospective data collection at single hospital sites (Table 3). Most studies used pre-post interventional designs ( $n=8 ; 80 \%)$, and all but one study occurred in a paediatric cardiac ICU ( $n=9 ; 90 \%)$. Sample sizes ranged from 29 to 1,507 clinical handovers, 
with the majority of studies $(n=8 ; 80 \%)$ using sample sizes of less than 79 . Of the 10 reviewed studies eight measured information transfer $(n=8,80 \%)$, five measured handover duration $(n=5,50 \%)$, three measured technical error $(n=3,30 \%)$ and two measured high risk events ( $n=2,20 \%)$ (Table 4).

\section{Information Transfer}

The use of a structured clinical handover tool was found to improve information transfer, handover accuracy and item frequency when compared to pre-intervention verbal handovers. All seven interventional studies measuring information transfer reported reduced information omissions in the post intervention sample (Table 3). ${ }^{12,15-18,22,23}$ Itemised information transferred during handover was reported to have increased by approximately $25 \%$ in two

interventional studies. ${ }^{15,16}$ Results indicated that the amount of critical information transferred improved after the implementation of a structured handover protocol. ${ }^{16,18,22,23}$

\section{Handover Duration}

The use of structured handover protocols did not significantly change the duration of the clinical handover, when compared to unstructured verbal handovers. ${ }^{12,16,17,22,23}$ Changes in handover duration reported ranged between a decrease of 2 minutes to an increase of 2.8 minutes across five studies, when compared to non-structured handovers. ${ }^{12,16,17,22,23}$ All five

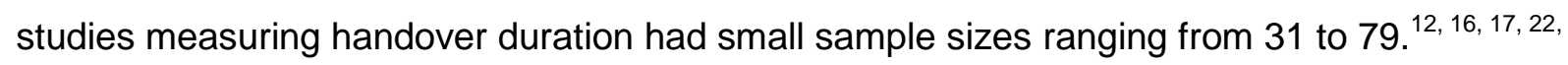
23

\section{Technical Error and High Risk Events}

The use of structured handover protocols was found to reduce post-handover technical errors, complications and high risk events. ${ }^{12,15,22}$ Technical errors were significantly reduced in two out of the three studies, with decreases of up to $76 \%{ }^{12,22}$ The third study also reported reduced technical errors however the results did not reach statistical significance. ${ }^{15}$ There was a correlation between poor technical handovers and higher information omissions 
during clinical handover reported, indicating a possible confounding effect with handover error. $^{22}$ Significant decreases in the incidence of high risk events including cardiopulmonary resuscitation, mediastinal re-exploration and metabolic acidosis were reported in one study, ${ }^{15}$ yet decreases in high risk events did not reach significance as reported in another. ${ }^{23}$

\section{Structured Handover Development}

There were several concepts that were common to the development of structured handover protocols. Information to be included in handover was decided by key stake holders $(n=8$, $80 \%)$, from previous research $(n=4,40 \%),{ }^{11,16,24,25}$ aviation and Formula 1 pit stop models $(n=1,10 \%),{ }^{22}$ or by identifying areas prone to high consequence error $(n=1,10 \%) .{ }^{12}$ All protocols used contextually developed checklists to structure and standardise clinical handovers ( $n=10,100 \%)$, often categorising information into demographics, patient history, anaesthesia information, surgical information and postoperative information $(n=6,60 \%) .{ }^{12,15-}$ $17,23,24$

\section{Discussion}

The evidence reported in our integrative review suggests that information transfer, posthandover technical errors and high risk events may be positively influenced by the use of structured clinical handover tools, however results are not consistent. Factors such as sample size, outcomes measured, context, patient complexity and clinical handover delivery formats have implications on the results reported in the included studies.

\section{Statistical and Clinical Significance}

Studies examining the impact of structured handover protocols often did not detect statistically significant differences in their results. Sample sizes were less than 80 in $80 \%$ of studies, possibly rendering them underpowered for analysis, thus unable to demonstrate any effect. $^{26}$ In contrast, results from other studies with larger sample sizes ( $n=1078$ and n=106) 
reported statistically significant reductions of high risk events with structured handovers between OT and ICU. ${ }^{15,27}$ Despite results not reaching statistical significance, many smaller studies examining the impact of structured handover protocols from OT to ICU still showed improvements in outcomes such as technical errors and high risk events. ${ }^{15}$

The clinical significance of the results from OT to ICU structured handover studies may be limited because many studies did not measure the impact of interventions on patient outcomes. Often 'softer' process or health professional outcomes were measured such as how many team members were present or provider satisfaction with handover. Evidencebased practice is evolving, shifting focus to clinically important outcomes which have direct impact on the patient such as morbidity and mortality. ${ }^{28,29}$ Demonstrating a benefit in clinical outcomes (e.g., mortality/morbidity) requires large sample sizes. Importantly, handover protocols are implemented for patient safety, with the intent of achieving effective and efficient communication at the time when the responsibility for clinical care is transferred. Demonstration of an improvement in the handover process, increased efficiency and provider satisfaction may be appropriate in the clinical setting. Implementing handover protocols as a means of quality improvement recognises the need to address issues around interdisciplinary communication.

\section{Context}

During this review we identified that clinical handover development was a context specific process within all studies. Recent publications on clinical handover have proposed that handover tools could be standardised and implemented on a wide scale across health care settings. ${ }^{3,7}$ While structured handover tools may improve the consistency of clinical handovers, due to their contextual nature it is doubtful that a standardised handover tool could be successfully implemented across different contexts. ${ }^{3}$ Previous studies which have 
shown rigid standardisation approaches with checklists can perform poorly when

implemented without flexibility in health care settings. ${ }^{9,}{ }^{30}$ Current National guidelines suggest flexible approaches to structured handover tool development, allowing them to be custom made for the context which they are performed. ${ }^{3}$ Similarly, information content included in handovers has been shown to benefit from key stakeholder development specific to the context, empowering staff members, improving compliance, and ensuring important information is transferred. ${ }^{8,9,30-32}$ Interestingly, all studies that successfully implemented structured handover processes were from specific contexts such as single hospital sites which were highly specialised such as paediatric cardiac ICUs. It remains unknown if the structured handover processes that were useful within specialised paediatric cardiac ICU context would achieve similar outcomes within different environments such as general adult ICUs.

Previous studies have implemented protocols from aviation and formula one racing into clinical handover practices. ${ }^{2,22}$ However, the fundamental difference in health care is teams are inconsistent and providers are likely to change frequently when compared to regular teams in other settings. ${ }^{33,34}$ Studies that have successfully implemented these concepts have applied them into highly specialised health care settings where there may also be greater team consistency and continuity of care. Previous results have related frequently changing teams with higher communication error, indicating that results may differ if implemented into a less consistent environment., ${ }^{9,13}$

There is a relationship between patient complexity with clinical handover information omissions and interruptions. Patients with greater surgical complexity and medical compromise were found to have less information transferred during handover, increasing the 
risk of communication error and potentially adverse events. One study demonstrated a positive relationship between patients surgical risk and information omissions. ${ }^{22}$ Similarly, a recent study revealed that more interruptions occur during handover of long term complex ICU patients when compared to shorter stay ICU patients. ${ }^{10}$ Excessive interruptions during handover of more complex long term ICU patients may reduce information retention, decision making, increasing error and adverse events in these most vulnerable patients. ${ }^{10,35}$ This indicates that handover on sicker patients may actually be less comprehensive and systematically structured, leading to increased error and poorer outcomes.

\section{Delivery Format}

We identified a variety of methods used to deliver clinical handovers across studies. Verbal handover accuracy and recall improved when combined with contextually developed checklists of structured handovers in all reviewed studies. These results are consistent previous studies which found the combined use of verbal handovers with checklists had more information transferred, less important data loss, and the greatest information recalled during simulated handovers. ${ }^{36,37}$ Handovers using verbal handover delivery alone had the least information transfer and recall, followed closely with the combination of verbal and note taking handovers. ${ }^{36,37}$ Research suggests that people may retain information in different ways. $^{38}$ Some participants may process information more successfully in written, visual or auditory delivery formats. ${ }^{38}$ It is possible that handovers which incorporate a mixture of verbal and written delivery may provide the best approach as they will appeal to a broader range of learning styles in participants.

The use of context specific checklists was related to the successful implementation of structured handover protocols. The results of reviewed studies are consistent with other research results that showed checklists increased consistency, information transfer, 
accuracy, and confidence in unfamiliar environments, allowed evaluation of health care processes, improved care, reduced mortality and morbidity. ${ }^{39}$ Similarly, recent studies suggest that check lists were more successfully implemented if direct care providers had developed and implemented the checklist with the belief that it would solve the clinical problem. ${ }^{39,40}$ However, other findings indicate that there are some negative impacts associated with using checklists. Checklists have been found to be laborious needing considerable resources to develop and can take staff away from immediate patient care. ${ }^{40,41}$ Others have suggested that the use of checklists may impede health care by encouraging a 'doing' tick and flick approach that may reduce practitioners 'thinking' about the items used. ${ }^{40}$ The use of electronic checklists has been reported as a popular and successful delivery technique although it was not evaluated in any of the studies included in this review. In our review, the successful implementation of structured handover protocols was more likely with the use of contextually developed checklists.

\section{Future Research}

Whilst the body of literature on structured clinical handover between OT and ICU is in its early stages of development, it has laid an important foundation for future research. The evidence described in this review suggests that future research using rigorous study designs broader populations and varied surgery presentations are needed to further evaluate the effect of clinical handover protocols. Future research also needs to explore the impact of using other innovative delivery formats, such as electronic checklists with verbal handovers, which may increase the quality and consistency of information transfer further.

\section{Limitations}

We acknowledge that this review and the studies included herein have limitations. First, limitations of the body of literature were that study designs, sample size and measurement 
were problematic. Rigorous study designs, broader populations with varied illness and surgery presentations across multiple sites are needed to evaluate the effect of clinical handover protocols.

We have applied a rigorous approach to conducting an integrative review. Nevertheless it is possible we may have overlooked some studies or reviews. Due to resource constraints only one author completed the data extraction and quality assessment of articles and therefore no reliability measures were completed. There is also the possibility of selection bias as our review was limited to studies reported in English. Therefore we may have missed important studies published in other languages.

\section{Conclusion}

In conclusion, information transfer, post-handover technical errors and high risk events were positively influenced by the use of structured clinical handover tools, however results are not consistent. Handover duration did not change using structured handover protocols despite more information being delivered Future research exploring innovative combination delivery formats, broader populations, varied surgery presentations and contexts are needed to strengthen evidence supporting the use of structured handover protocols. 


\section{References}

1. Mistry K, Jagers J, Lodge A, et al. Using six sigma methodology to improve handoff commnication in high risk patients. In: Agency for Healthcare Research and Quality's (AHRQ), (ed.). . 2008.

2. Dunn E, Mills P, Neily J, Crittenden M, Carmac A and Bagian J. Medical team training: applying crew resource management in the Veterans Health Administration. The Joint Commision Journal on Quality and Patient Safety. 2007; 33: 317-25.

3. Australian Commission on Safety and Quality in Health Care. Standard 6: Clinical handover. Safety and quality improvement guide,. In: ACSQHC, (ed.). Sydney2012.

4. Australian Institute of Health and Welfare and the Australian Commission on Safety and Quality in Health Care. Sentinel events in Australian public hospitals 2004-05,. Australian Institute of Health and Welfare. 2007; 2: 1-44.

5. Gawande AA, Zinner MJ, Studdert DM and Brennan TA. Analysis of errors reported by surgeons at three teaching hospitals. Surgery. 2003; 133: 614-21.

6. Kohn LT, Corrigan JM and Donaldson MS. To err is human: building a safer health system. National Academies Press, 2000.

7. World Health Organization. World Alliance for Patient Safety Progress Report 2006-2007, Geneva: World Health Organization,, 2008.

8. Bonifacio A, Segall N, Barbeito A, Taekman J, Schroeder R and Mark J. Handovers from the OR to ICU,. International Anesthesiology Clinics. 2013; 51: 43-61.

9. Queensland Health Patient Safety Centre. Clinical handover $(\mathrm{CH})$ : a strategy options paper. Consultation draft,. In: Centre for healthcare improvement, (ed.). Queensland: Queensland Government, 2009, p. 1-45.

10. Spooner AJ, Corley A, Chaboyer W, Hammond NE and Fraser JF. Measurement of the frequency and source of interruptions occurring during bedside nursing handover in the intensive care unit: An observational study. Australian Critical Care. 2014.

11. Kaufman J. A handoff protocol from the cardiovascular operating room to the cardiac ICU is associated with improvements in care beyond the immediate postoperative period,. The Joint Commision Journal on Quality and Patient Safety. 2013; 39: 306-12.

12. Joy B. Standardised multidisciplinary protocol improves handover of cardiac surgey patients to the intensive care unit,. Pediatric Critical Care Medicine. 2011.

13. Zwarenstein $\mathrm{M}$ and Bryant $\mathrm{W}$. Interventions to promote collaboration between nurses and doctors. Cochrane Database of Systemic reviews. 2009: 1-12.

14. Segall N, Bonifacio AS, Schroeder RA, et al. Can We Make Postoperative Patient Handovers Safer? A Systematic Review of the Literature. Anesthesia \& Analgesia. 2012; 115: 102-15 10.1213/ANE.0b013e318253af4b.

15. Argwal H, Saville B, Slayton J, et al. Standardized postoperative handover process improves outcomes in the intensive care unit: A model for operational sustainabilty and improved team performance,. Critical Care Medicine. 2012; 40: 2109-15.

16. Karakaya A, Moerman A, Peperstraete H, Francois K, Wouters P and de Hert S. Implementation of a strctured information transfer checklist improves postoperative data transfer after congenital cardiac surgery,. European Journal of Anaesthesiology. 2013; 30: 764-9. 
17. Petrovic MA, Aboumatar $\mathrm{H}$, Baumgartner WA, et al. Pilot implementation of a perioperative protocol to guide operating room-to-intensive care unit patient handoffs. Journal of cardiothoracic and vascular anesthesia. 2012; 26: 11-6.

18. Vergales J, Addison N, Vendettelli A, et al. Face-to-face handoff: improving transfer to the paediatric intensive care unit after cardiac surgey,. American Journal of Medical Quality. 2014: 1-7. 19. Whittemore R and Knafl K. The integrative review: updated methodology. Journal of Advanced Nursing. 2005; 52: 546-53.

20. Polit DF and Beck CT. Nursing research: generating and assessing evidence for nursing practice. 9th edition ed. Philadelphia: Wolters Kluwer Health/ Lippincott Williams \& Wilkins, 2012. 21. Kmet LM, Lee RC and Cook LS. Standard quality assessment criteria for evaluating primary research papers from a variety of fields. Alberta Heritage Foundation for Medical Research, 2004. 22. Catchpole K. Patient handover from surgery to intensive care: using formula 1 pit-stop and aviation models to improve safety and quality. Pediatric Anesthesia. 2007; 17: 470-8.

23. Zavalkoff SR, Razack SI, Lavoie J and Dancea AB. Handover after pediatric heart surgery: a simple tool improves information exchange. Pediatric critical care medicine : a journal of the Society of Critical Care Medicine and the World Federation of Pediatric Intensive and Critical Care Societies. 2011; 12: 309-13.

24. Craig R, Moxey L, Young D, Spenceley NS and Davidson MG. Strengthening handover communication in pediatric cardiac intensive care. Pediatric Anesthesia. 2012; 22: 393-9.

25. Chen JG, Wright MC, Smith PB, Jaggers J and Mistry KP. Adaptation of a postoperative handoff communication process for children with heart disease: a quantitative study. American journal of medical quality : the official journal of the American College of Medical Quality. 2011; 26: 380-6.

26. Hertzog MA. Considerations in determining sample size for pilot studies. Research in Nursing \& Health. 2008; 31: 180-91.

27. Kim SW, Maturo S, Dwyer D, et al. Interdisciplinary Development and Implementation of Communication Checklist for Postoperative Management of Pediatric Airway Patients.

Otolaryngology -- Head and Neck Surgery. 2012; 146: 129-34.

28. Hague J. Patient-oriented evidence that matters: POEMs. EJHP. 2004; 2: 56-7.

29. Vanhook PM. Overcoming the barriers to EBP. Nursing management. 2009; 40: 9-11.

30. Lillrank $P$ and Liukko M. Standard, routine and non-rouine processes in health care, International Jouranl of Health Quality Assurance,. 2004; 17: 39-46.

31. Strange F. Handover: an ethnographic study of ritual in nursing practice,. Intensive and Critical Care Nursing. 1996; 12: 106-12.

32. Hann M, Bower P, Campbell S, Marshall M and Reeves D. The association between culture, climate and quality care in primary health care teams,. Family Practice. 2007: 323-9.

33. Wohlauer MV, Arora VM, Horwitz LI, Bass EJ, Mahar SE and Philibert I. The patient handoff: a comprehensive curricular blueprint for resident education to improve continuity of care. Academic medicine: journal of the Association of American Medical Colleges. 2012; 87: 411.

34. Toff NJ. Human factors in anaesthesia: lessons from aviation. British Journal of Anaesthesia. 2010; 105: 21-5.

35. McGillis L, Pedersen C and Fairely L. Losing the moment: Understanding interruptions to nurse's work. The Journal of Nursing Administration. 2010; 40: 169-76.

36. Pothier D, Monteiro P, Mooktiar M and Shaw A. Handover. Pilot study to show the loss of important data in nursing handover. British Journal of Nursing. 2005; 14: 1090-3.

37. Bhabra G, Mackeith S, Monteiro P and Pothier DD. An experimental comparison of handover methods. Annals of The Royal College of Surgeons of England. 2007; 89: 298-300.

38. Dawson C. The Complete Study Skills Guide: A practical guide for all students who want to know how to learn. Constable \& Robinson Ltd, 2013. 
39. Thomassen O, Espeland A, Softeland E, Lossius HM, Heltne JK and Brattebo G.

Implementation of checklists in health care; learning from high-reliability organisations. Scandinavian journal of trauma, resuscitation and emergency medicine. 2011; 19: 53.

40. Rosen MA and Pronovost PJ. Advancing the Use of Checklists for Evaluating Performance in Health Care. Academic Medicine. 2014; Publish Ahead of Print: 10.1097/ACM.0000000000000285.

41. Thomassen O, Brattebo G, Heltne JK, Softeland E and Espeland A. Checklists in the operating room: Help or hurdle? A qualitative study on health workers' experiences. BMC Health Serv Res.

2010; 10: 342. 


\begin{tabular}{|c|c|c|}
\hline Term & Definition & Source \\
\hline Clinical Handover & $\begin{array}{l}\text { The transfer of the patient, information, equipment, professional responsibility and } \\
\text { accountability from one professional person or group to another. }\end{array}$ & 3,8 \\
\hline Verbal Handover & $\begin{array}{l}\text { The delivery of information by a team member without following a pre-existing } \\
\text { structure or protocol; includes handovers made before standardisation of } \\
\text { structured handover processes. }\end{array}$ & 12 \\
\hline Structured Handover & $\begin{array}{l}\text { Contextual standardisation of technical and information handover by required } \\
\text { team members in a structured format; may include the use of checklists; in a face } \\
\text { to face format. }\end{array}$ & 3 \\
\hline Information Handover & $\begin{array}{l}\text { Has previously been defined as the transfer of important information that is crucial } \\
\text { for the continuation of patient care }\end{array}$ & 19 \\
\hline $\begin{array}{l}\text { Information Handover } \\
\text { Error }\end{array}$ & $\begin{array}{l}\text { The omission of important information that is crucial for the continuation of patient } \\
\text { care. }\end{array}$ & 19 \\
\hline Technical Handover & $\begin{array}{l}\text { Has previously been defined as the transfer of equipment or technology, and } \\
\text { includes ventilation, monitoring, pumps, equipment, drains, and lines }\end{array}$ & 19 \\
\hline Technical Handover Error & $\begin{array}{l}\text { Any transfer of equipment or technology that has been performed incorrectly or } \\
\text { with unusual difficulty. }\end{array}$ & 19 \\
\hline Handover Duration & $\begin{array}{l}\text { The time interval from the moment the patient enters the ICU to the moment the } \\
\text { OT team leave the bedside. }\end{array}$ & 19 \\
\hline Team Members Present & $\begin{array}{l}\text { Any health care professional present for the handover and such as surgical, } \\
\text { medical, anaesthetic, nursing and other health care staff, having varied levels of } \\
\text { experience and qualifications }\end{array}$ & 17 \\
\hline A High Risk Event & $\begin{array}{l}\text { Any unplanned change in a patient's condition that may have serious impact on } \\
\text { their recovery. High risk events include accidental extubation, high carbon dioxide, } \\
\text { pneumothorax, cardiac arrest, return to theatre, arrhythmias, loss of arterial or } \\
\text { central lines, loss of drains, } \mathrm{pH}<7.25 \text { or }>7.55 \text {, seizure or death }\end{array}$ & 3,15 \\
\hline
\end{tabular}




\begin{tabular}{|c|c|}
\hline Data Base & Search Terms \\
\hline CINHAL ${ }^{K, S T, T, A T}$ & Handover OR Handoff \\
\hline PROQUEST ${ }^{K, A, F T}$ & AND Operating Theatre OR Operating Room or Perioperative \\
\hline PubMed ${ }^{\mathrm{K}, \mathrm{ST}, \mathrm{T}}$ & AND Intensive Care OR Critical Care \\
\hline \multirow{3}{*}{$\begin{array}{l}\text { Cochrane Library }{ }^{\mathrm{M}, \mathrm{TA}} \\
\text { EMBASE }^{\mathrm{M}, \mathrm{TA}}\end{array}$} & "Handover" OR "Handoff" \\
\hline & AND “Operating Room” \\
\hline & AND "Intensive Care" OR “Critical Care" \\
\hline
\end{tabular}

A-abstract only, AT-all text; FT-full text; K-key word; M-medical subject heading (MeSH); ST-smart text searching, T-title; TA-title and abstract. 


\begin{tabular}{|c|c|c|c|c|c|c|c|}
\hline $\begin{array}{l}\text { Lead } \\
\text { Author, } \\
\text { (Year), } \\
\text { Location }\end{array}$ & Setting, Sample & Design & Aim & Measures & Key Findings & Limitations & $\begin{array}{l}\text { Quality } \\
\text { Score }\end{array}$ \\
\hline $\begin{array}{l}\text { Agarwal, } \\
\text { (2012), US }\end{array}$ & $\begin{array}{ll}\text { - } & \text { Single } \\
\text { hospital site } \\
\text { OT- } \\
\text { Paediatric } \\
\text { cardiac ICU } \\
\text { - } 700 \text { verbal } \\
\text { (July 2007- } \\
\text { June 2009) } \\
\text { and 378 } \\
\text { structured } \\
\text { handovers } \\
\text { (July 2009- }\end{array}$ & 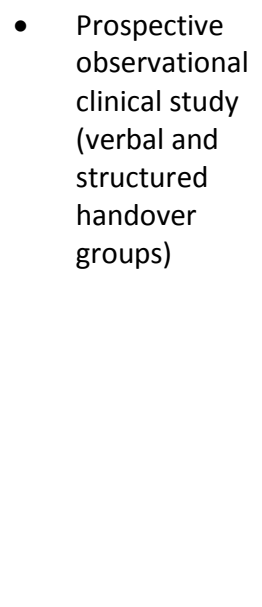 & $\begin{array}{l}\text { Determine if use of a } \\
\text { structured handover } \\
\text { tool from OT to } \\
\text { paediatric cardiac ICU } \\
\text { following cardiac } \\
\text { surgery is associated } \\
\text { with a reduction in the } \\
\text { loss of information } \\
\text { transfer and } \\
\text { improvement in the } \\
\text { quality of } \\
\text { communication } \\
\text { exchange. }\end{array}$ & $\begin{array}{l}\text { - Information transfer } \\
\text { of patient } \\
\text { information, } \\
\text { preoperative, } \\
\text { anaesthesia, surgical, } \\
\text { postoperative } \\
\text { details, and } \\
\text { laboratory values } \\
\text { Complications in the } \\
\text { first } 24 \text { hours } \\
\text { - Extubation in the } \\
\text { first } 24 \text { hours }\end{array}$ & $\begin{array}{l}\text { - Complications in first } 24 \\
\text { hours in ICU reduced } \\
\text { from } 100 \% \text { to } 12 \% \\
\text { ( } p<0.001) \text {. } \\
\text { - Successful extubation in } \\
\text { first } 24 \text { hours increased } \\
\text { from } 43.2 \% \text { to } 50 \% \\
\text { ( } p=0.04) . \\
\text { - Structured handover } \\
\text { improved information } \\
\text { transfer, reduced } \\
\text { postoperative } \\
\text { complications, and } \\
\text { improved } 24 \text { hour patient } \\
\text { outcomes. }\end{array}$ & 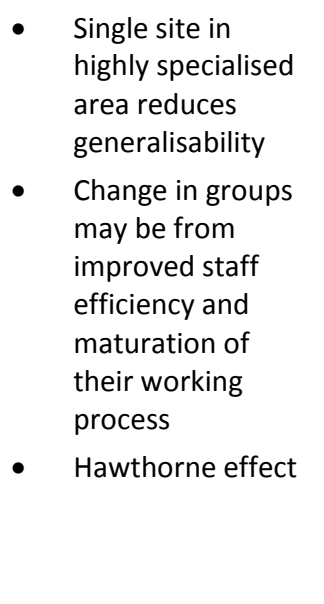 & $\begin{array}{l}19 / 28 \\
(68 \%)\end{array}$ \\
\hline $\begin{array}{l}\text { Catchpole, } \\
\text { (2007), UK }\end{array}$ & $\begin{array}{l}\text { - } \quad \text { Single } \\
\text { hospital site } \\
\text { OT to } \\
\text { paediatric } \\
\text { cardiac ICU } \\
\text { - } 50 \text { patient } \\
\text { handovers } \\
\text { (23 pre, } 27 \\
\text { post) }\end{array}$ & $\begin{array}{l}\text { Pilot study, } \\
\text { prospective } \\
\text { pre post } \\
\text { intervention } \\
\text { study }\end{array}$ & $\begin{array}{l}\text { Improve the quality } \\
\text { and safety of } \\
\text { handover of patients } \\
\text { from surgery to ICU } \\
\text { using the analogy of } \\
\text { the formula } 1 \text { pit stop } \\
\text { and expertise from } \\
\text { aviation. }\end{array}$ & $\begin{array}{ll}\text { - } & \text { Technical errors } \\
\text { - } & \text { Handover } \\
\text { information } \\
\text { - } & \text { Overall handover } \\
\text { duration } \\
\text { - Team performance }\end{array}$ & $\begin{array}{l}\text { - Mean technical errors } \\
\text { reduced from } 5.42(95 \% \\
\mathrm{Cl} \pm 1.24) \text { to } 3.15(95 \% \mathrm{Cl} \\
\pm 0.71) \text {. } \\
\text { - } \text { Mean handover } \\
\text { omissions reduced from } \\
2.09(95 \% \mathrm{Cl} \pm 1.14) \text { to } \\
1.07(95 \% \mathrm{Cl} \pm 0.55) . \\
\text { Mean handover duration } \\
\text { reduced from } 10.8 \text { min } \\
(95 \% \mathrm{Cl} \pm 1.6) \text { to } 9.4 \mathrm{~min} \\
(95 \% \mathrm{Cl} \pm 1.29) \text { not } \\
\text { significant }\end{array}$ & $\begin{array}{ll}\text { - } & \text { Pilot/ feasibility } \\
\text { study but 'tests for } \\
\text { effect'- not a } \\
\text { feasibility criteria } \\
\text { - } \quad \text { Sample size } \\
\text { appears small for } \\
\text { the analysis. } \\
\text { Single site \& } \\
\text { specialised area } \\
\text { reduces } \\
\text { generalisability }\end{array}$ & $\begin{array}{l}16 / 28 \\
(57 \%)\end{array}$ \\
\hline
\end{tabular}




\begin{tabular}{|c|c|c|c|c|c|c|c|}
\hline $\begin{array}{l}\text { Lead } \\
\text { Author, } \\
\text { (Year), } \\
\text { Location }\end{array}$ & Setting, Sample & Design & Aim & Measures & Key Findings & Limitations & $\begin{array}{l}\text { Quality } \\
\text { Score }\end{array}$ \\
\hline $\begin{array}{l}\text { Chen, } \\
\text { (2011), US }\end{array}$ & $\begin{array}{ll}\text { - } & \text { Single } \\
\text { hospital site } & \\
\text { OT-Cardiac } \\
\text { surgery } \\
\text { paediatric } \\
\text { ICU } \\
\text { - } 29 \\
\text { handovers } \\
\text { events from } \\
\text { Jan 2008- } \\
\text { Aug 2008 }\end{array}$ & $\begin{array}{l}\text { - Observational } \\
\text { cross-sectional } \\
\text { study }\end{array}$ & $\begin{array}{l}\text { - To understand how } \\
\text { users adapt handover } \\
\text { process over time by } \\
\text { evaluating the present } \\
\text { process }\end{array}$ & $\begin{array}{ll}\text { - } & \text { Presence of } \\
\text { interdisciplinary } \\
\text { team members } \\
\text { during handover } \\
\text { - } \quad \text { Item frequency } \\
\text { during the handover } \\
\text { - } \quad \text { Number of } \\
\text { distractions } \\
\text { occurring during } \\
\text { handover }\end{array}$ & $\begin{array}{l}\text { - } \quad \text { Individuals present }=97 \% \\
\text { - } 53 \% \\
\text { - } \quad \text { Bed side nurse } \\
\text { announced sterile cock- } \\
\text { pit and initiated handover } \\
\text { communication } 21 \% \text { of } \\
\text { the time. } \\
\text { - } \quad \text { Total of } 2.3 \\
\text { environmental } \\
\text { distractions per minute of } \\
\text { communication. } \\
\text { Question time at the end } \\
67 \% \text { of the time. }\end{array}$ & 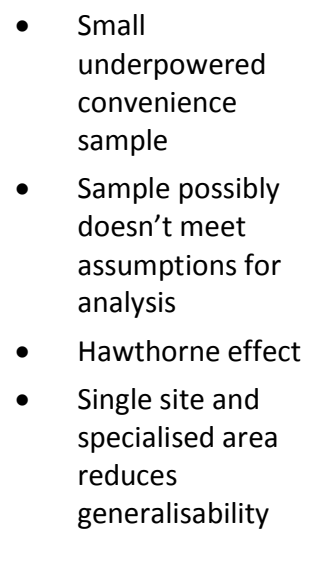 & $\begin{array}{l}16 / 28 \\
(57 \%)\end{array}$ \\
\hline $\begin{array}{l}\text { Craig, } \\
\text { (2011), UK }\end{array}$ & $\begin{array}{ll}\text { - } & \text { Single } \\
\text { tertiary } & \text { hospital site } \\
\text { paediatric } & \text { ICU } \\
\text { providing } & \text { both general } \\
\text { and cardiac. } \\
\text { Total } 43 \\
\text { handovers } \\
\text { (handovers } \\
21 \text { pre, } 22 \\
\text { post). }\end{array}$ & $\begin{array}{l}\text { Prospective } \\
\text { pre and post } \\
\text { interventional } \\
\text { study. }\end{array}$ & $\begin{array}{l}\text { - To investigate the } \\
\text { effect of the } \\
\text { implementation of a } \\
\text { structured handover } \\
\text { in the intensive care } \\
\text { unit. }\end{array}$ & $\begin{array}{ll}\text { - } & \text { Pre-handover } \\
\text { - } & \text { readiness. } \\
\text { Information } \\
\text { - } \\
\text { - Standover readiness. } \\
\text { - } & \text { Organisation of the } \\
\text { handover. } \\
\text { - }\end{array}$ & $\begin{array}{l}\text { - Improved handover } \\
\text { attentiveness, } \\
\text { organisation, information } \\
\text { flow, and fewer } \\
\text { interruptions. } \\
\text { - Improved staff } \\
\text { perceptions (readiness } \\
\text { for the patient, \& ability } \\
\text { to focus on the } \\
\text { handover). } \\
\text { - Improved communication } \\
\text { between OT and ICU } \\
\text { staff. } \\
\text { No increase in handover } \\
\text { duration }\end{array}$ & $\begin{array}{l}\text { - } \quad \begin{array}{l}\text { Sample size seems } \\
\text { small to test for } \\
\text { effect, similar } \\
\text { sample size to a } \\
\text { pilot study. }\end{array} \\
\text { - } \quad \text { Hawthorne effect } \\
\text { - } \\
\text { Single site in a } \\
\text { specialised area } \\
\text { reduces } \\
\text { generalisability. }\end{array}$ & $\begin{array}{l}14 / 28 \\
(50 \%)\end{array}$ \\
\hline
\end{tabular}




\begin{tabular}{|c|c|c|c|c|c|c|c|}
\hline $\begin{array}{l}\text { Lead } \\
\text { Author, } \\
\text { (Year), } \\
\text { Location }\end{array}$ & Setting, Sample & Design & Aim & Measures & Key Findings & Limitations & $\begin{array}{l}\text { Quality } \\
\text { Score }\end{array}$ \\
\hline $\begin{array}{l}\text { Joy, (2011), } \\
\text { US }\end{array}$ & $\begin{array}{l}\text { - } \quad \text { Single } \\
\text { hospital site } \\
\text { paediatric } \\
\text { cardiac ICU. } \\
\text { - } \quad 79 \text { patient } \\
\text { handovers } \\
\text { (41 pre, } 38 \\
\text { post). }\end{array}$ & $\begin{array}{ll}\text { - } & \text { Prospective } \\
\text { pre-post } \\
\text { interventional } \\
\text { study. }\end{array}$ & $\begin{array}{l}\text { Determine whether } \\
\text { the implementation of } \\
\text { a standardised } \\
\text { handover protocol } \\
\text { could reduce the } \\
\text { number of errors } \\
\text { occurring during } \\
\text { patient transitions } \\
\text { from the OT to ICU. }\end{array}$ & $\begin{array}{ll}\text { - } & \text { Technical errors. } \\
\text { - } & \text { Information } \\
\text { omissions } \\
\text { - } & \text { Proportion of } \\
& \text { realised errors out of } \\
\text { total errors. } \\
\text { - }\end{array}$ & $\begin{array}{l}\text { - Critical verbal handoff } \\
\text { omissions were reduced } \\
\text { from } 6.33 \text { to } 2.38 \\
(p<0.001) \text {. } \\
\text { - } \quad \text { Mean technical errors per } \\
\text { handover was } \\
\text { significantly reduced } \\
\text { from } 6.24 \text { to } 1.52 \\
\text { ( } p<0.001) \text {. } \\
\text { No increase of handover } \\
\text { duration. }\end{array}$ & 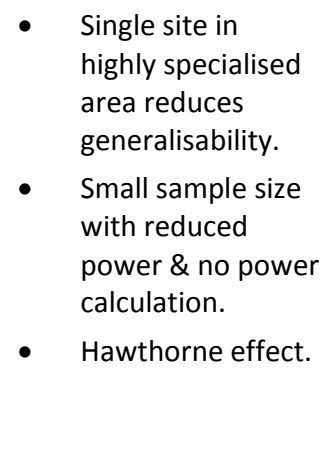 & $\begin{array}{l}17 / 28 \\
(61 \%)\end{array}$ \\
\hline $\begin{array}{l}\text { Karakaya, } \\
\text { (2013), } \\
\text { Belgium }\end{array}$ & $\begin{array}{l}\text { - Single } \\
\text { hospital site } \\
\text { OT- } \\
\text { Paediatric } \\
\text { cardiothoraci } \\
\text { c ICU. } \\
\text { - } 48 \text { paediatric } \\
\text { cardiac } \\
\text { surgery. } \\
\text { Power } \\
\text { calculation } \alpha \\
0.05 \& \\
\text { Berror of } 0.8 \\
=\text { sample } 40 .\end{array}$ & $\begin{array}{l}\text { - Prospective } \\
\text { pre/post } \\
\text { interventional } \\
\text { clinical study. }\end{array}$ & $\begin{array}{l}\text { Test the hypothesis- } \\
\text { the implementation of } \\
\text { a standardised } \\
\text { checklist used during } \\
\text { verbal patient } \\
\text { handover could } \\
\text { improve postoperative } \\
\text { data transfer after } \\
\text { congenital heart } \\
\text { surgery. }\end{array}$ & $\begin{array}{ll}\text { - } & \text { Data transferred on } \\
\text { itemised checklist. } \\
\text { - } \quad \text { Interruptions and } \\
\text { irrelevant data. } \\
\text { - } \quad \text { Confusing pieces of } \\
\text { information. } \\
\text { - } \quad \text { Handover duration. } \\
\text { - } 1 \text { hour post- } \\
\text { handover interview } \\
\text { on handover } \\
\text { evaluation. }\end{array}$ & 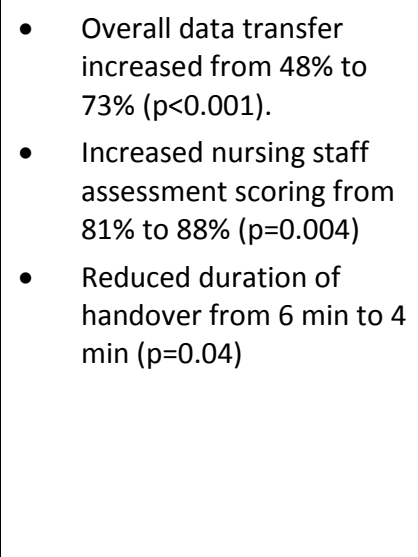 & $\begin{array}{l}\text { - Sample size seems } \\
\text { small, the design is } \\
\text { to 'test for effect' } \\
\text { yet it has used a } \\
\text { pilot sample size. } \\
\text { - Single site in } \\
\text { highly specialised } \\
\text { area reduces } \\
\text { generalisability. } \\
\text { - Hawthorne effect. }\end{array}$ & $\begin{array}{l}18 / 28 \\
(64 \%)\end{array}$ \\
\hline
\end{tabular}




\begin{tabular}{|c|c|c|c|c|c|c|c|}
\hline $\begin{array}{l}\text { Lead } \\
\text { Author, } \\
\text { (Year), } \\
\text { Location }\end{array}$ & Setting, Sample & Design & Aim & Measures & Key Findings & Limitations & $\begin{array}{l}\text { Quality } \\
\text { Score }\end{array}$ \\
\hline $\begin{array}{l}\text { Kaufman, } \\
\text { (2013), US }\end{array}$ & \begin{tabular}{|l} 
- \\
Single \\
hospital OT- \\
Neonatal, \\
paediatric \\
and adults \\
cardiac ICU \\
- Pre 621 (Jan \\
2009-May \\
2010), post \\
886 (June \\
2010-Dec \\
2011).
\end{tabular} & $\begin{array}{ll}\text { - } & \text { Prospective } \\
\text { pre-post } \\
\text { interventional } \\
\text { study. }\end{array}$ & $\begin{array}{l}\text { - Assess benefits and } \\
\text { improvements in care } \\
\text { following the adoption } \\
\text { of a handoff protocol. } \\
\text { - As a parallel project an } \\
\text { initiative to reduce } \\
\text { unplanned } \\
\text { extubations in the } \\
\text { CICU was } \\
\text { implemented. }\end{array}$ & $\begin{array}{ll}\text { - } & \text { Number of surgical } \\
\text { cases. } \\
\text { - } \quad \text { Percentage of } \\
\text { neonatal surgeries. } \\
\text { - } \quad \text { Total ventilator } \\
\text { days. } \\
\text { - } \quad \text { Surgical mortality } \\
\text { rate. } \\
\text { Monthly unplanned } \\
\text { extubation rates. }\end{array}$ & $\begin{array}{l}\text { Post intervention- } \\
\text { significant reduction of } \\
\text { unexplained extubation } \\
\text { events from } 0.62 \text { to } 0.24 \\
\text { per } 100 \text { ventilator days ( } p \\
=0.03 \text { ). } \\
\text { - } \\
\text { Significant reduction in } \\
\text { median ventilator time } \\
\text { per patient from } 17 \text { hours } \\
\text { (IQR: } 5.3-57.7) \text { to } 12.8 \\
\text { hours (IQR: } 4.8-31.8) \text { ( } p \\
=0.02 \text { ). }\end{array}$ & $\begin{array}{ll}\text { - } & \text { Single site in } \\
& \text { highly specialised } \\
\text { area reduces } \\
\text { generalisability. } \\
\text { - } & \text { Hawthorne effect. }\end{array}$ & $\begin{array}{l}15 / 28 \\
(54 \%)\end{array}$ \\
\hline $\begin{array}{l}\text { Petrovic, } \\
\text { (2012), US } \\
\text { (Pilot } \\
\text { study). }\end{array}$ & $\begin{array}{l}\text { - } \\
\text { Single } \\
\text { hospital site } \\
\text { OT-Adult } \\
\text { cardiac } \\
\text { surgery ICU } \\
\text { - } 60 \text { patients } \\
\text { (30 pre, } 30 \\
\text { post (Dec } \\
\text { 2008-June } \\
\text { 2009). }\end{array}$ & $\begin{array}{l}\text { - } \quad \text { Pilot } \\
\text { prospective } \\
\text { pre-post } \\
\text { interventional } \\
\text { study. }\end{array}$ & $\begin{array}{l}\text { Evaluate the impact of } \\
\text { a standardised } \\
\text { handoff process on (1) } \\
\text { patient care and (2) } \\
\text { provider satisfaction. }\end{array}$ & 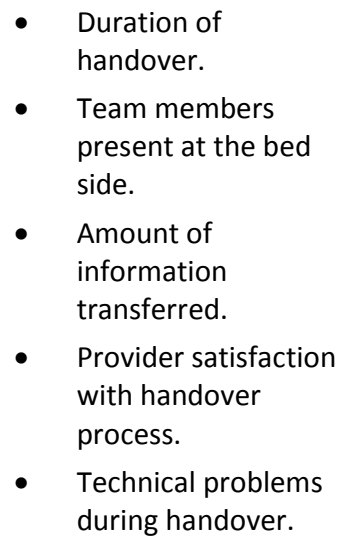 & $\begin{array}{l}\text { - } \quad \text { Team members at bed } \\
\text { side increased from } 0 \% \text { to } \\
68 \% \text { ( }<<0.001 \text { ). } \\
\text { - Information sharing } \\
\text { increased from } 78 \% \text { to } \\
84 \% \text { ( } p<0.01 \text { ). } \\
\text { - Improved satisfaction of } \\
\text { ICU nurses (the most) and } \\
\text { ICU practitioners. } \\
\text { - Reduced technical error } \\
\text { (forgot chart, missing } \\
\text { patient ID). }\end{array}$ & $\begin{array}{ll}\text { - } & \text { Single hospital site } \\
\text { in highly } \\
\text { specialised area } \\
\text { reduces } \\
\text { generalisability } \\
\text { - } & \text { Pilot/ feasibility } \\
\text { study but tests for } \\
\text { effect-not a } \\
\text { feasibility criteria } \\
\text { - Hawthorne effect }\end{array}$ & $\begin{array}{l}20 / 28 \\
(71 \%)\end{array}$ \\
\hline
\end{tabular}




\begin{tabular}{|c|c|c|c|c|c|c|c|}
\hline $\begin{array}{l}\text { Lead } \\
\text { Author, } \\
\text { (Year), } \\
\text { Location }\end{array}$ & Setting, Sample & Design & Aim & Measures & Key Findings & Limitations & $\begin{array}{l}\text { Quality } \\
\text { Score }\end{array}$ \\
\hline $\begin{array}{l}\text { Vergales, } \\
\text { (2014), US }\end{array}$ & 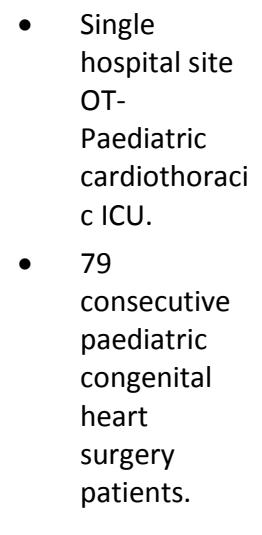 & $\begin{array}{l}\text { Pilot study } \\
\text { prospective, } \\
\text { pre-test post- } \\
\text { test. }\end{array}$ & $\begin{array}{l}\text { Develop \& implement } \\
\text { a primary face to face } \\
\text { handover process } \\
\text { from OT to ICU for } \\
\text { paediatric congenital } \\
\text { heart surgery patients. }\end{array}$ & 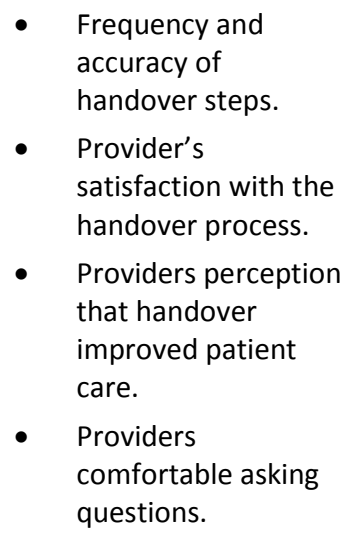 & $\begin{array}{l}\text { - } 94 \% \text { felt patient care was } \\
\text { improved post } \\
\text { intervention. } \\
\text { - } \quad \text { High compliance to new } \\
\text { process across disciplines. } \\
\text { (e.g. } 100 \% \text { compliance of } \\
\text { ICU going to OT to collect } \\
\text { the patient). } \\
\text { - Perceived improved } \\
\text { efficiency by staff. } \\
\text { Complex patients can be } \\
\text { handed over in same } \\
\text { duration. }\end{array}$ & $\begin{array}{ll}\text { - } & \text { Pilot/ feasibility } \\
\text { study } \\
\text { underpowered to } \\
\text { test for effect } \\
\text { - } \quad \text { Single site in a } \\
\text { highly specialised } \\
\text { area reduces } \\
\text { generalisability. } \\
\text { - } \quad \text { Hawthorne effect }\end{array}$ & $\begin{array}{l}17 / 28 \\
(60 \%)\end{array}$ \\
\hline $\begin{array}{l}\text { Zavalkoff, } \\
\text { (2011), } \\
\text { Canada }\end{array}$ & $\begin{array}{l}\text { Single } \\
\text { hospital site } \\
\text { tertiary care, } \\
\text { paediatric } \\
\text { intensive } \\
\text { care unit } \\
31 \\
\text { handovers } \\
\text { (15 pre, } 16 \\
\text { post) }\end{array}$ & $\begin{array}{l}\text { - } \quad \text { Prospective } \\
\text { pre-post } \\
\text { interventional } \\
\text { study (not } \\
\text { blinded) }\end{array}$ & $\begin{array}{l}\text { Improve the quality of } \\
\text { handover for complex } \\
\text { patients after } \\
\text { paediatric cardiac } \\
\text { surgery through the } \\
\text { use of a simple } \\
\text { handover tool. } \\
\text { Determine the tools } \\
\text { impact on handover } \\
\text { duration \& HRE in the } \\
\text { initial postoperative } \\
\text { period. }\end{array}$ & $\begin{array}{l}\text { - Handover } \\
\text { completeness } \\
\text { (preoperative, } \\
\text { intraoperative } \\
\text { medical, } \\
\text { intraoperative } \\
\text { surgical, and current } \\
\text { status) } \\
\text { - } \text { Number of post- } \\
\text { handover HRE } \\
\text { - Handover duration }\end{array}$ & $\begin{array}{l}\text { - Handover completeness } \\
\text { increased significantly. } \\
\text { - } \quad \text { Significant improvement } \\
\text { of medical \& surgical } \\
\text { intraoperative } \\
\text { information sub scores. } \\
\text { - No change handover } \\
\text { duration. } \\
\text { Non-significant decrease } \\
\text { HRE }\end{array}$ & $\begin{array}{l}\text { - Small sample size } \\
\text { \& reduced power, } \\
\text { no power } \\
\text { calculation } \\
\text { - } \quad \text { Single site in } \\
\text { highly specialised } \\
\text { area reduces } \\
\text { generalisability } \\
\text { - } \\
\text { Hawthorne effect }\end{array}$ & $\begin{array}{l}21 / 28 \\
(75 \%)\end{array}$ \\
\hline
\end{tabular}




\begin{tabular}{|c|c|c|c|c|c|c|c|c|c|c|}
\hline $\begin{array}{l}\text { Lead Author, } \\
\text { Year }\end{array}$ & $\begin{array}{l}\text { Agarwa } \\
\text { I (2012) }\end{array}$ & $\begin{array}{l}\text { Catchp } \\
\text { ole } \\
(2007)\end{array}$ & $\begin{array}{l}\text { Chen } \\
(2011)\end{array}$ & $\begin{array}{l}\text { Craig } \\
(2011)\end{array}$ & $\begin{array}{l}\text { Joy } \\
\text { (2011) }\end{array}$ & $\begin{array}{l}\text { Karaka } \\
\text { ya } \\
(2013)\end{array}$ & $\begin{array}{l}\text { Kaufma } \\
\text { n } \\
(2013)\end{array}$ & $\begin{array}{l}\text { Petrovi } \\
\text { c } \\
(2012)\end{array}$ & $\begin{array}{l}\text { Vergale } \\
\text { S } \\
\text { (2014) }\end{array}$ & $\begin{array}{l}\text { Zavalko } \\
\mathrm{ff} \\
(2011)\end{array}$ \\
\hline \multicolumn{11}{|l|}{$\begin{array}{l}\text { Handover } \\
\text { completeness/ } \\
\text { item frequency }\end{array}$} \\
\hline \multicolumn{11}{|l|}{$\begin{array}{l}\text { Handover } \\
\text { duration }\end{array}$} \\
\hline \multicolumn{11}{|l|}{$\begin{array}{l}\text { Number of } \\
\text { interruptions or } \\
\text { distractions }\end{array}$} \\
\hline \multicolumn{11}{|l|}{$\begin{array}{l}\text { Technical } \\
\text { problems/ } \\
\text { errors }\end{array}$} \\
\hline \multicolumn{11}{|l|}{$\begin{array}{l}\text { Post-handover } \\
\text { high risk events }\end{array}$} \\
\hline \multicolumn{11}{|l|}{$\begin{array}{l}\text { Team members } \\
\text { present }\end{array}$} \\
\hline $\begin{array}{l}\text { Provider } \\
\text { satisfaction }\end{array}$ & & & & & & & & & & \\
\hline
\end{tabular}




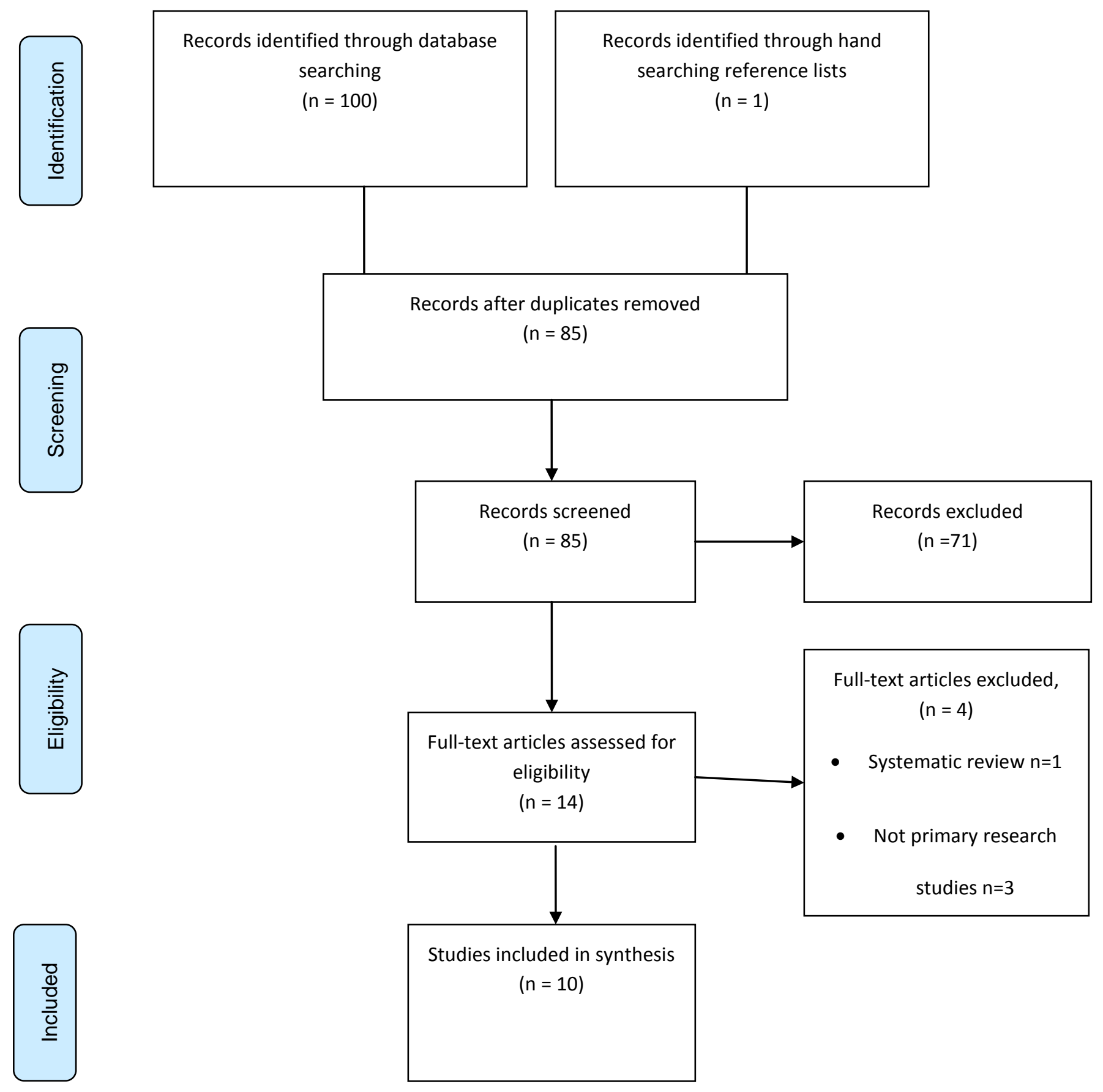

Figure 1. PRISMA Flow Diagram. 